« Die Bedeutung der phönizischen Tempel von Umm el-Amed für die Religionsgeschichte der Levante in vorhellenistischer Zeit ", in : M. Witte, J. F. Diehl, eds., Israeliten und Phönizier. Ihre Beziehungen im Spiegel der Archäologie und der Literatur des Alten Testaments und seiner Umwelt. Fribourg/Göttingen, 2008, p. 125-164. (OBO 235)

Astrid Nunn

\title{
OpenEdition Journals
}

\section{Édition électronique}

URL : http://journals.openedition.org/abstractairanica/39184

DOI : 10.4000/abstractairanica.39184

ISSN : 1961-960X

Éditeur:

CNRS (UMR 7528 Mondes iraniens et indiens), Éditions de l'IFRI

Édition imprimée

Date de publication : 15 mai 2011

ISSN : 0240-8910

\section{Référence électronique}

Astrid Nunn, « « Die Bedeutung der phönizischen Tempel von Umm el-Amed für die Religionsgeschichte der Levante in vorhellenistischer Zeit », in : M. Witte, J. F. Diehl, eds., Israeliten und Phönizier. Ihre Beziehungen im Spiegel der Archäologie und der Literatur des Alten Testaments und seiner Umwelt. Fribourg/Göttingen, 2008, p. 125-164. (OBO 235) », Abstracta Iranica [En ligne], Volume 31 | 2011, document 47, mis en ligne le 15 février 2012, consulté le 02 octobre 2020. URL : http:// journals.openedition.org/abstractairanica/39184; DOI : https://doi.org/10.4000/abstractairanica. 39184

Ce document a été généré automatiquement le 2 octobre 2020. 
« Die Bedeutung der phönizischen Tempel von Umm el-Amed für die Religionsgeschichte der Levante in vorhellenistischer Zeit ", in : M. Witte, J. F. Diehl, eds., Israeliten und Phönizier. Ihre Beziehungen im Spiegel der Archäologie und der Literatur des Alten Testaments und seiner Umwelt. Fribourg/Göttingen, 2008, p. 125-164. (OBO 235)

Astrid Nunn 
1 L'A. étudie les temples phéniciens d'Umm el-Amed dans l'optique du petit colloque, dont les actes sont publiés dans le vol. OBO 235 et dont le thème était le rapport entre les Israélites et les Phéniciens dans la seconde moitié du premier millénaire av. J.-C. (cf. aussi c.r. $\left.n^{\circ} 46,53\right)$. Ce site, situé au sud de Tyr, a été identifié et fouillé par E. Renan, et plus tard par M. Dunand et R. Duru. Il connut son apogée au III ${ }^{\mathrm{e}}$ et II ${ }^{\mathrm{e}} \mathrm{s}$. av. J.-C. mais un sondage dans le temple de Milkaštart, de la céramique et quelques trouvailles prouvent que le site était déjà habité à l'époque achéménide. Les temples de l'époque hellénistique sont peu hellénisés et ont livré deux trônes aux sphinx, comme on se les imagine dans le temple de Jérusalem (cf. A. Nunn, Trans. 35). Ils permettent ainsi la possibilité d'un aperçu sur l'architecture et les cultes phéniciens ainsi que, selon l'A., une illustration des liens entre la Phénicie et Israël.

INDEX

Thèmes : 3.2.2. Pré-Achéménides et Achéménides

\section{AUTEURS}

\section{ASTRID NUNN}

Université de Munich 